\title{
PENGARUH KUALITAS PELAYANAN TERHADAP KEPUASAN NASABAH BANK MANDIRI KCM JAKARTA RAYA KOSAMBI JAKARTA BARAT
}

\author{
Ali Mubarok *) \\ Email : alimubarok1310@gmail.com \\ Abdullah Syafi'ie **)
}

\begin{abstract}
ABSTRAK
Penelitian ini bertujuan untuk mengetahui pengaruh kualitas pelayanan terhadap Kepuasan Nasabah PT. Bank Mandiri KCM Jakarta Raya Kosambi Jakarta Barat. Sampel penelitian sejumlah 85 orang nasabah, sample diambil dengan teknik random sampling.

Data primer diperoleh dengan metode survey menggunakan quesioner. Data dianalisis dengan analisis uji koefisien determinasi, uji hipotesis, deskriptif, korelasi, dan regresi sederhana. Sebelum data dianalisis terlebih dahulu dilakukan uji validitas dan reliabilitas.

Hasil analisis deskriptif menunjukkan bahwa persepsi nasabah terhadap kualitas pelayanan adalah baik dengan total jawaban setuju dan sangat setuju sebesar $70,7 \%$. Begitu pula untuk kepuasan nasabah dalam kategori baik dengan mayoritas 78,1\% membrikan jawaban setuju dan sangan setuju. Di sisi lain pada hasil uji hipotesis menghasilkan nilai 11,34. Hasil analisis korelasi menunjukkan adanya hubungan positif dan berkategori kuat antara kualitas pelayanan dengan kepuasan nasabah dengan nilai koefisien korelasi 0,7796. Hasil analisis regresi menunjukkan bahwa pengaruh kualitas pelayanan terhadap kepuasan nasabah dengan koefisiensi regresi 0,38 . Sedangkan tingkat kontribusi koefisien determinasi pada kualitas pelayanan menghasilkan nilai $60,78 \%$. Sisanya sebesar $39,22 \%$ dipengaruhi oleh faktor lain yang tidak diteliti dalam peneliti ini.
\end{abstract}

Kata Kunci : kualitas pelayanan, kepuasan nasabah, produk jasa, PT. Bank Mandiri (Persero) Tbk (KCM Jakarta Raya Kosambi) Jakarta Barat.

\section{A. Pendahuluan}

Bank dapat dipahami sebagai lembaga keuangan yang memberikan kontribusi dalam perkembangan dan pertumbuhan suatu bangsa, tak terkecuali Indonesia. Keberadaan bank maupun lembaga keuangan yang lain semakin tahun terus bertambah, tentunya persaingan dalam dunia bisnis semakin tajam. Persaingan dalam dunia bisnis sangatlah ketat sehingga pelaku bisnis diharuskan untuk memberikan pelayanan yang optimal dan dapat memberikan solusi dari setiap harapan konsumen, sehingga konsumen akan merasa puas dengan pelayanan yang diberikan oleh perusahaan dan akan menjadi konsumen yang loyal.

Cara pengungkapannya dari setiap perusahaanpun juga beragam, ada yang menyebutnya memberikan segala sesuatu yang diharapkan setiap pelanggan, pelanggan adalah raja, kepuasan pelanggan adalah tujuan kami, dan lain sebagainya. Situasi ini terjadi pada semua sektor tanpa terkecuali baik swasta ataupun instansi pemerintah, dari uraian diatas sangat jelas kualitas pelayanan dan kepuasan 
pelanggan adalah kunci dari kegiatan usaha yang dijalankan, dengan memuaskan konsumen perusahaan akan mampu bersaing dengan pengusaha lain bahkan akan mampu mempertahankan eksistensinya.

Banyak penelitian telah dilakukan untuk meneliti bahwa kualitas pelayanan dapat mempengaruhi kepuasan pelanggan. Irawan (2004) bahwa faktor yang menciptakan kepuasan pelanggan adalah keramahan dan kesopanan pramusaji, kelayakan dan kebersihan toilet serta wastfel, sarana parkir dan kenyamanan.

PT. Bank Mandiri (Persero) Tbk merupakan perusahaan yang bergerak di bidang jaasa perbankan milik negara, yang berkantor pusat di Jl. Jend. Gatot Subroto kav. 3638 Jakarta Selatan. Bank Mandiri merupakan salah satu bank BUMN terbesar di Indonesia yang memiliki nasabah yang tersebar hingga ke pelosok daerah di Indonesia. Dalam perjalanan di dunai perbankan, Bank Mandiri memiliki fungsi hampir diseluruh sektor baik dalam bisnis komersil, maupun bisnis retail. Namun dengan berkembangan zaman, bisnis retail ternyata mampu memberikan kontribusi yang cukup signifikan. Oleh karena itu pada tahun 2004, PT. Bank Mandiri menciptakan Mandiri Mitra Usaha, atau biasa disebut Mikro Mandiri yang khusus untuk menajalankan sektor retail dalam hal kredit untuk masyarakat kecil dan menengah.

Kaitannya dengan penjelasan di atas, berhubungan dengan kondisi riil di lapangan yang penulis temukan. Salah satunya pada PT. Bank Mandiri (Persero) Tbk (KCM Jakarta Raya Kosambi) Jakarta Barat, dimana penulis menemukan adanya keluhankeluahan dari nasabah yang artinya kepuasan nasabah belum maksimal.

\begin{tabular}{|c|l|c|c|c|}
\hline \multirow{2}{*}{ No } & \multicolumn{1}{|c}{ Uraian } & \multicolumn{3}{|c}{ Bulan Junii s.d Aggustus } \\
\cline { 3 - 5 } & & Juni & Juli & Agustus \\
\hline 1 & $\begin{array}{l}\text { Jangka waktu dalam proses alur jalannya } \\
\text { kredit masih tergolong lama. }\end{array}$ & 3 & 4 & 2 \\
\hline 2 & Lahan parkir yang kurang memadai. & 12 & 7 & 11 \\
\hline 3 & $\begin{array}{l}\text { Kesigapan dan ketelitian dalam memberikan } \\
\text { pelayanan masih kurang. }\end{array}$ & 5 & 4 & 5 \\
\hline 4 & Produknya kurang berfariatif. & 3 & 1 & 2 \\
\hline 5 & Promosi yang dilakukan kurang maksimal. & 1 & 3 & 0 \\
\hline 6 & Masih sering terlihat adanya antrian. & 3 & 8 & 7 \\
\hline 7 & $\begin{array}{l}\text { Fasilitas yang disediakan masih kurang } \\
\text { memadai. }\end{array}$ & 3 & 3 & 5 \\
\hline 8 & $\begin{array}{l}\text { Masih banyak nasabah yang memberikan } \\
\text { komplain. }\end{array}$ & 4 & 5 & 6 \\
\hline
\end{tabular}

Dari tabel diatas, terlihat bahwa masih adanya nasabah pada Bank Mandiri KCM Jakarta Raya Kosambi yang merasa tidak puas,ini diduga akibat dari kualitas pelayanan yang kurang baik. Hal ini harus diperhatikan oleh pihak manajemen Bank Mandiri KCM Jakarta Raya Kosambi kedepannya. 


\begin{tabular}{|l|c|c|c|}
\hline \multirow{2}{*}{ Bulan } & \multicolumn{3}{|c|}{ Jumlah Nasabah } \\
\cline { 2 - 4 } & Tabungan & Pinjaman & Deposito \\
\hline Juni & 7 & 2 & 0 \\
\hline Juli & 13 & 1 & 0 \\
\hline Agustus & 4 & 1 & 0 \\
\hline
\end{tabular}

Dampak dari Tabel 1.1 diatas, terlihat pada Tabel 1.2 bahwa jumlah Nasabah yang melakukan pembukaan rekening baik rekening Tabungan, rekening Deposito maupun rekening Giro di Bank Mandiri KCM Jakarta Raya Kosambi mengalami penurunan. Setelah melihat fenomena yang terjadi pada Bank Mandiri KCM Jakarta Raya Kosambi, Peneliti memutuskan untuk mengambil tema "Pengaruh Kualitas Pelayanan Terhadap Kepuasan Nasabah Pada PT. Bank Mandiri (Persero) Tbk (KCM Jakarta Raya Kosambi)".

\section{B. Perumusan Masalah}

Berdasarkan Uraian diatas maka dapat dirumuskan permasalahan dalam penelitian ini antara lain:

1. Bagaimana Kualitas Pelayanan pada Mandiri Mitra Usaha Cabang Jakarta Raya Kosambi?

2. Bagaimana kepuasan nasabah terhadap kualitas pelayanan Mandiri Mitra Usaha Cabang Jakarta Raya Kosambi?

3. Seberapa besar pengaruh kualitas pelayanan terhadap kepuasan nasabah pada Mandiri Mitra Usaha Cabang Jakarta Raya Kosambi?

\section{Tujuan Penelitian}

Penelitian dilakukan dengan tujuan sebagai berikut :

a. Untuk mengetahui Kualitas Pelayanan pada Mandiri Mitra Usaha Cabang Jakarta Raya Kosambi.

b. Untuk mengetahui seberapa besar kepuasan nasabah pada Mandiri Mitra Usaha Cabang Jakarta Raya Kosambi.

c. Untuk mengetahui seberapa besar Pengaruh Kualitas Pelayanan Mandiri Mitra Usaha Cabang Jakarta Raya Kosambi terhadap kepuasan nasabah pada Mandiri Mitra Usaha Cabang Jakarta Raya Kosambi.

\section{Landasan Teori}


Pelayanan adalah suatutindakan yang dilakukan untuk memenuhi kebutuhan pelanggan pada tingkat pemuasan yang hanya dapat dirasakan pada orang yang melayani dan dilayani saja. Pelayanan adalah aktivitas atau manfaat yang ditawarkan berwujud dan tidak menghasilkan apapun. Produknya mungkin tidak terikat atau tidak terkait pada produk fisik, Kotler (2005). Dari pengertian diatas maka peneliti mengambil kesimpulan bahwa pelayanan merupakan kegiatan atau usaha yang dilakukan untuk memenuhi kebutuhan dan keinginan orang lain atau pelanggan.

Menurut Fandi Tjiptono, Gregorius Chandra, Dadi Adriana dalam bukunya Pemasaran Strategik (2008:443) didalam penawaran produk fisik kerap kali kita juga tidak dapat terlepas dari unsur layanan pelengkap (supplementary service) yang biasa diklasifikasikan kedalam delapan kelompok yang disebut "The Flower Of Service". (Lovelock:1994).

a. Informasi

b. Konsultasi

c. Order taking

d. Hospitality.

e. Caretaking

f. Expection

g. Billing

h. Pembayaran.

Kualitas pelayanan yang unggul dapat memberikan banyak benefit bagi perusahaan salah satunya adalah dengan terjalinnya hubungan baik antara perusahaan dan pelanggannya sehingga pelanggan yang puas akan melakukan pembelian ulang dan bahkan akan merekomendasikannya ke calon pelanggan yang lain dan pada akhirnya ini akan mampu meningkatkan keuntungan bagi perusahaan.

Sifat-sifat khusus jasa yang menyatakan "diberikan oleh suatu pihak kepada pihak lain yg pada dasarnya tidak berwujud dan tidak mengakibatkan terjadinya perpindahan kepemilikan" perlu diperhatikan dan dipertimbangkan dalam merancang program pemasaran. Kottler (2000:429). Perbedaan jasa dan barang dapat dilihat dari karakteristiknya. Jasa memiliki empat ciri utama yang sangat mempengaruhi rancangan program pemasaran yaitu :

a. Tidak berwujud (intangibility)

Hal ini menyebabkan konsumen tidak dapat melihat, mencium, meraba, mendengar dan merasakan hasilnya sebelum mereka membelinya. Untuk mengurangi ketidak puasan, konsumen akan mencari informsi tentang jasa tersebut, seperti lokasi 
perusahaan, para penyediaan dan penyalur jasa, peralatan dan alat komunikasi yang akan digunakan serta harga produk jasa tersebut. Beberapa hal yang dapat dilakukan perusahaan untuk meningkatkan kepercayaan calon nasabah yaitu :

1) Meningkatkan visualisasi jasa yang tidak berwujud menjadi berwujud.

2) Menekankan pada manfaat yang diperoleh.

3) Menciptakan suatu nama merk (brand name) bagi jasa.

4) Memakai nama orang terkenal untuk meningkatkan kepercayaan nasabah.

b. Tidak terpisah (inseparability)

Jasa tidak bisa dipisahkan dari sumbernya, yaitu perusahaan jasa yang menghasilkannya. Jasa produksi dan konsumsi pada saat bersamaan. Jika nasabah menggunakan jasa maka ia akan berhadapan langsung dengan sumber atau penyedia jasa tersebut, sehingga penjualan jasa lebih diutamakan untuk penjualan langsung dengan skala operasi terbatas. Untuk mengatasi maslah ini, perusahaan dapat menggunakan strategi-strategi seperti, bekerja dalam kelompok yang lebih besar, bekerja lebih cepat, serta me;atih pemberi jasa supaya mereka mampu membina kepercayaan nasabah.

c. Bervariasi (variability)

Jasa yang diberikan sering kali berubah-ubah tergantung dari siapa yang menyajikan, kapan dan dimana penyajian jasa tersebut dilakukan, ini mengabiatkan sulitnya menjaga kualitas jasa berdasarkan suatu standar.

Menurut Philip Kotler (2001:42) menyatakan bahwa kepuasan adalah perasaan senang atau kecewa seseorang yang muncul setelah membandingkan antara pesepsi atau kesannya terhadap kinerj atau hasil suatu produk dan harapan-harapanya.

Sedangkan menurut Tse dan Wilton sebagian dikutip oleh Fandy Tjiptono (2005:197) menyatakan bahwa "kepuasan pelanggan adalah respon pelanggan terhadap evaluasi perbedaan antara ekspektasi awal dan kinerja aktual produk sebagaimana dipersiapkan setelah konsumsi produk".

Dari definisi diatas dapat ditarik kesimpulan bahwa pada dasarnya pengertian kepuasan pelanggan mencakup perbedaan antara harapan dan kinerja atau hasil yang dirasakan. Karna pelanggan adalah orang yang menerima hasil pekerjaan dari suatu organisasi, maka hanya merekalah yang dapat menentukan kualitasnya seperti apa dan hanya merekalah yang dapat menyampaikan apa dan bagaimana kebutuhan mereka. Hal inilah yang menyebabkan kualitas yang populer berbunyi, "Kualitas Dimulai Dari Pelanggan". 
Menurut Irawan (2008:3) kepuasan pelanggan adalah hasil akumulasi dari konsumen atau pelanggan dalam menggunakan produk atau jasa. Pelanggan puas setelah membeli produk dan menggunakan produk tersebut, ternyata kualitasnya baik. Oleh karna itu, setiap pengalaman baru akan memberikan pengaruh terhadap kepuasan pelanggan. Pelanggan yang puas akan berbagi kepuasan dengan produsen atau penyedia jasa. Bahkan pelanggan yang puas akan berbagi rasa dan pengalaman dengan pelanggan lain.

Dalam penelitian ini,indikator kepuasan pelanggan menurut Hawkins dan Lonney dikutip Tjiptono (2004:101) adalah sebagai berikut:

a. Kesesuaian jasa dengan yang diharapkan

Merupakan tingkat kesesuaian antara kinerja produk yang diharapkan oleh pelanggan dengan yang dirasakan oleh pelanggan.

b. Merekomendasikan pada pihak lain

Merupakan kesediaan pelanggan untuk merekomendasikan produk yang telah dirasakannya kepada teman atau kerabat.

Akan menggunakan jasa kembali Merupakan kesediaan pelanggan untuk berkunjung kembali atau melakukan pembelian ulsng terhadap produk terkait.

Perencanaan, implementasi dan pengendalian program kepuasan konsumen memberikan berbagai manfaat bagi perusahaan anatara lain :

a. Manfaat Ekonomis

Berbagai studi menunjukan bahwa mempertahankan dan memuaskan nasabah saat ini murah dibandingkan terus menerus berupaya untuk menarik atau memprospek nasabah baru, Riset Wells menunjukan biaya mempertahankan nasabah lebih murah enam kali lipat dibandingkan biaya mencari nasabah baru.

b. Kunci sukse dimasa depan

1) Kepuasan nasabah merupakan strategi bisnis jangka panjang, membangun dan memperoleh reputasi produk perusahaan dibutuhkan waktu yang cukup lama, diperlukan investasi besar pada serangkaian aktivitas bisnis untuk membahagiakan nasabah.

2) Kepuasan konsumen merupakan indikator kesuksesan bisnis dimasa depan yang mengukur kecenderungan reaksi nasabah terhadap perusahaan dimasa yang akan datang.

3) Program kepuasan nasabah relatif mahal dan hanya mendatangkan laba jangka panjang yang bertahan lama. 
4) Ukuran kepuasan konsumen lebih prediktif untuk kinerja masa depan sekalipun tidak mengabaikan data akuntansi sekarang.

\section{E. Metodologi}

Penelitian ini dilaksanakan di PT. Bank Mandiri (Persero) Tbk (KCM Jakarta Raya Kosambi) yang beralamat di Komplek Perum Kosambi Baru Blok D Ext 5 Kav 26A Duri Kosambi Cengkareng Jakarta Barat Tlp. 02154377118 Fax.54377116.

Penelitian dilakukan dari bulan juni 2018 - Agustus 2018, Penelitian dilakukan secara bertahap, diawali dengan persiapan penelitian, observasi, pembuatan kuesioner, pemberian kuesioner kepada nasabah, penarikan kuesioner, pengolahan dan analisa data.

Metode penelitian yang digunakan adalah metode asosiatif dengan pendekatan kuantitatif. Pendekatan kuantitatif menerangkan pada makna, penalaran, definisi suatu situasi tertentu (dalam konteks tertentu), lebih banyak meneliti hal-hal yang berhubungan dengan sehari-hari. Pendekatan kuantitatif, lebih lanjut, mementingkan pada proses dibandingkan dengan hasil akhir, oleh karena itu uruturutan kegiatan dapat berubah-ubah tergantung pada kondisi dan banyaknya gejala-gejala yang ditemukan.

Populasi dalam penelitian ini adalah Nasabah pada Mandiri Mitra Usaha Cabang Jakarta Raya Kosambi dengan jumlah populasi sebanyak 555 Nasabah pada periode 10 Oktober 2015 sampai 30 November 2018. Dan pengambilan sampel ditentukan dalam bentuk teknik sampling. Sugiyono (2013:81). Sampel yang baik adalah sampel yang memiliki populasi secara keseluruhan. Sedangkan Teknik pengambilan sampel ini adalah teknik Probability Sampling. Berdasarkan perhitungan maka jumlah sample yang digunakan dalam penelitian ini adalah 85 responden dari jumlah populasi sebesar 555 Nasabah, maka ditentukan dari taraf errornya (Tingkat kesalahan) 10\%, jadi jumlah sampel yaitu 85 responden.

\section{F. Hasil dan Pembahasan}

1. Karakteristik Responden

a. Responden menrut jenis kelamin

\begin{tabular}{|c|c|c|}
\hline Jenis kelamin & Total & Persentase \\
\hline Laki-laki & 30 & $35,30 \%$ \\
\hline Perempuan & 55 & $64,70 \%$ \\
\hline Total & 85 & $100 \%$ \\
\hline
\end{tabular}

\section{b. Responden menurut usia}




\begin{tabular}{|c|c|c|}
\hline Usia & Total & Persentase \\
\hline$<21$ tahun & 0 & $0 \%$ \\
\hline $21-30$ tahun & 20 & $23,53 \%$ \\
\hline $31-40$ tahun & 35 & $41,17 \%$ \\
\hline $41-50$ tahun & 17 & $20,00 \%$ \\
\hline$>50$ tahun & 13 & $15,30 \%$ \\
\hline TOTAL & 85 & $100 \%$ \\
\hline
\end{tabular}

c. Responden menurut jenis pekerjaan

\begin{tabular}{|c|c|c|}
\hline Pekerjaan & Total & Persentase \\
\hline PNS/POLRI/TNI/BUMN & 3 & $3,53 \%$ \\
\hline Karyawan swasta & 13 & $15,30 \%$ \\
\hline Wirausaha & 64 & $75,29 \%$ \\
\hline Ibu Rumah Tangga & 5 & $5,88 \%$ \\
\hline Pelajar/ Mahasiswa & 0 & $0 \%$ \\
\hline TOTAL & 85 & $100 \%$ \\
\hline
\end{tabular}

\section{d. Responden menurut pendidikan}

\begin{tabular}{|c|c|c|}
\hline Pendidikan & Total & Persentase \\
\hline SMU/sederajat & 81 & $95,30 \%$ \\
\hline Diploma (D3) & 1 & $1.17 \%$ \\
\hline Sarjana (S1) & 3 & $3,53 \%$ \\
\hline Magister (S2) & 0 & $0 \%$ \\
\hline Total & 85 & $100 \%$ \\
\hline
\end{tabular}

\section{e. Rata-rata Pengeluaran per Bulan Responden}

\begin{tabular}{|c|c|c|}
\hline $\begin{array}{c}\text { Penghasilan per } \\
\text { bulan }\end{array}$ & Total & Persentase \\
\hline$<$ Rp. $1.000 .000,-$ & 0 & $0 \%$ \\
\hline $\begin{array}{c}\text { Rp.1.000.000,-s/d } \\
\text { Rp.2.000.000,- }\end{array}$ & 0 & $0 \%$ \\
\hline $\begin{array}{c}\text { Rp.2.000.000,-s/d } \\
\text { Rp.3.000.000,- }\end{array}$ & 20 & $23,53 \%$ \\
\hline $\begin{array}{c}\text { Rp.3.000.000,-s/d } \\
\text { Rp.4.000.000,- }\end{array}$ & 20 & $23,53 \%$ \\
\hline $\begin{array}{c}\text { Rp4.000.000,-s/d } \\
\text { Rp. } 5.000 .000,-\end{array}$ & 28 & $32,94 \%$ \\
\hline$>$ Rp.5.000.000,- & 17 & $20,00 \%$ \\
\hline Total & 85 & $100 \%$ \\
\hline
\end{tabular}

\section{Analisa Statistik Deskriptif Kualitas Pelayanan (X)}

Data persepsi kualitas pelayanan diperoleh 85 responden yang terdiri dari 10 item pernyataan. Tanggapan tersebut kemudian dianalisa oleh peneliti dengan menggunakan jumlah presentase tanggapan. Analisis Kualitas Pelayanan (X) Berdasarkan Jumlah Kategori Tanggapan.

Berdasarkan hasil uji deskriptif kualitas pelayanan dapat dilihat bahwa dari keseluruhan responden yang berjumlah 85 orang dengan total pernyataan 850 soal, yang menjawab "sangat tidak setuju "sebanyak 4 atau 0,5\%, jawaban "tidak setuju" sebanyak 44 atau 5,2\%, jawaban "cukup setuju" sebanyak 201 atau 23,6\%, jawaban "setuju" sebanyak 420 atau 49,4\%, dan jawaban "sangat setuju" sebanyak 181 atau $21,3 \%$. 
Berdasar observasi dan hasil kuesioner tersebut, dengan mayoritas responden memberikan jawaban "setuju" sebanyak 49,4\%, dan "sangat setuju" sebanyak $21,3 \%$ sehingga total jawaban "setuju" dan "sangat setuju" adalah sebesar 70,7\%, maka penulis menyimpulkan kualitas pelayanan di Bank Mandiri KCM Jakarta Raya Kosambi dinilai baik. Nasabah sudah aware atau perduli atas pelayanan yang diberikan oleh karyawan Bank Mandiri KCM Jakarta Raya Kosambi.

\section{Analisa Statistik Deskriptif Kepuasan Nasabah (Y)}

Data persepsi pemasaran online diperoleh 85 responden yang terdiri dari 6 item pertanyaan. Tanggapan tersebut kemudian dianalisa oleh peneliti dengan menggunakan jumlah presentase tanggapan.

Dari hasil penyebaran 6 pernyataan tentang kepuasan nasabah $(Y)$ yang diberikan kepada seluruh responden berjumlah 85 orang.

Berdasarkan data dapat dilihat bahwa dari keseluruhan responden yang berjumlah 85 orang dengan total 510 pernyataan, yang menjawab "sangat tidak setuju " sebanyak 2 atau 0,4\%, jawaban "tidak setuju" sebanyak 10 atau 1,9\%, jawaban "cukup setuju" sebanyak 100 atau 19,6\%, jawaban "setuju" sebanyak 275 atau 54\%, dan jawaban "sangat setuju" sebanyak 123 atau $24,1 \%$.

Berdasar observasi dan hasil kuesioner tersebut, dengan mayoritas responden memberikan jawaban "setuju" sebanyak 54\%, dan "sangat setuju" sebesar $24,1 \%$ sehingga total persentase jawaban "setuju" dan "sangat setuju" adalah sebesar 78,1\%, maka penulis menyimpulkan bahwa kepuasan nasabah Bank Mandiri KCM Jakarta Raya Kosambi dinilai "Baik".

\section{Hasil Analisis Data}

\section{a. Hasil Uji Validitas}

Uji validitas berguna untuk mengetahui apakah adanya pertanyaan-pertanyaan pada kuisioner yang harus dibuang/diganti karena dianggap tidak relevan atau digunakan untuk menguji valid atau tidak setiap item pernyataan atau pertanyaan pada kuisioner yang disebarkan pada responden.

Uji validitas dilakukan dengan membandingkan nilai $r$ hitung dengan $r$ tabel. Jika $r$ hitung $>$ $r$ tabel dan nilai positif maka butir pernyataan tersebut dinyatakan valid (Imam Ghozali, 2005).

\section{1) Variabel Kualitas Pelayanan $(X)$}

Berdasarkan perhitungan didapat diketahui bahwa $r$ hitung $=0,701$ sedangkan $r$ tabel dapat dilihat pada tabel dengan cara jumlah responden ( 85 orang) dikurang jumlah 
variabel 2 atau $d f=n-2$. Dalam hal ini $d f=85-2=83$. sehingga $r$ tabel diketahui sebesar 0,2133

Melalui perhitungan yang sudah dilakukan untuk butir pernyataan nomor satu didapatkan hasil $r$ hitung $>r$ tabel dimana 0,701 $>0,2133$, sehingga pernyataan nomor satu dinyatakan valid.

Berdasar tabel dapat dilihat bahwa dari nilai keseluruhan koefisien korelasi $r$ hitung memiliki nilai yang lebih besar daripada $r_{\text {tabel, atau }} r_{\text {hitung }}$ lebih besar dari 0,2133. Oleh karena itu dapat disimpulkan bahwa ke-10 pernyataan tersebut adalah valid. Butir yang memiliki validitas tertinggi adalah butir ke-7 yaitu 0,837 dan yang terendah adalah butir ke-4 yaitu 0,673

\section{2) Variabel Kepuasan Nasabah (Y)}

Berdasarkan perhitungan dapat diketahui bahwa $r$ hitung $=0,670$, sedangkan $r$ tabel dapat dilihat pada tabel dengan cara jumlah responden (85 orang) dikurang jumlah variabel 2 atau $d f=n-2$. Dalam hal ini $d f=85-2=83$. sehingga $r$ tabel diketahui sebesar 0,2133 .

Melalui perhitungan yang sudah dilakukan untuk butir pernyataan nomor satu didapatkan hasil $r$ hitung $>r_{\text {tabel }}$ dimana $0,670>0,2133$, sehingga pernyataan nomor satu dinyatakan valid.

Berdasar tabel didapat dilihat bahwa dari nilai keseluruhan $r$ hitung memiliki nilai yang lebih besar daripada $r_{\text {tabel, }}$ atau $r_{\text {hitung }}$ lebih besar dari 0,2133. Oleh karena itu dapat disimpulkan bahwa ke-6 pernyataan tersebut adalah valid. Butir yang memiliki validitas tertinggi adalah butir ke-2 yaitu 0,760 dan yang terendah adalah butir ke-6 yaitu 0,668 .

\section{b. Hasil Uji Reliabilitas}

Uji reliabilitas dilakukan untuk mengetahui apakah instrument yang digunakan oleh peneliti memiliki nilai yang tetap bila instrument tersebut digunakan berulang oleh siapapun dan kapanpun pada tempat penelitian yang sama.

Berikut adalah langkah-langkah untuk menguji reliabilitas pernyataan dalam kuesioner.

a. Uji Reliabilitas Instrumen X (Kualitas Pelayanan) dengan metode cronbach alpha:

1) Langkah 1 : Mencari Varian Butir Variabel Kualitas Pelayanan ( $X)$

2) Langkah 2 : menghitung jumlah total varian semua butir pernyataan

3) Langkah 3 : mencari varian total

4) Langkah 4 : menghitung nilai Reliabilitas Alpha 
Berdasarkan hasil perhitungan reliabilitas manual, dapat disimpulkan bahwa seluruh pernyataan adalah Reliabel. Hal ini dapat dilihat dari nilai Cronbach Alpha yang lebih besar dari tingkat reliabel $>0,60$. Nilai rca juga lebih besar jika dibandingkan dengan nilai $r_{\text {tabel }}$ yaitu 0,926 >0,2133. Jika diinterpretasikan berdasarkan koefisien menurut Guilford, maka butir pernyataan pada variabel $X$ berada di antara nilai 0,70 - < 0,90 atau dianggap Sangat Reliabel.

b. Uji Reliabilitas Instrumen Y (Kepuasan Nasabah) dengan metode cronbach alpha:

1) Langkah 1 : Mencari Varian Butir Variabel Kepuasan Nasabah (Y)

2) Langkah 2 : menghitung jumlah total varian semua butir pernyataan

3) Langkah 3 : mencari varian total

4) Langkah 4 : menghitung nilai Reliabilitas Alpha

Berdasarkan hasil perhitungan reliabilitas manual, dapat disimpulkan bahwa seluruh pernyataan adalah Reliabel. Hal ini dapat dilihat dari nilai Cronbach Alpha yang lebih besar dari tingkat reliabel $>0,60$. Nilai rca juga lebih besar jika dibandingkan dengan nilai $r$ tabel yaitu 0,745 $>0,2133$. Jika diinterpretasikan berdasarkan koefisien menurut Guilford, maka butir pernyataan pada variabel $X$ berada di antara nilai 0,70 - $<0,90$ atau dianggap Sangat Reliabel.

Hasil nilai reliabilitas ini menunjukkan bahwa data variabel $X$ dan $Y$ dikatakan sangat reliabel (terpercaya). Dengan kata lain terdapat konsistensi dari responden dalam menjawab kuesioner yang diajukan dalam penelitian. Hal ini dapat diartikan bahwa pernyataan-pernyataan dalam kuisioner berapa kalipun ditanyakan kepada responden akan menghasilkan hasil ukur yang sama.

\section{c. Hasil Uji Regresi Linier Sederhana}

Untuk lebih menentukan pengaruh antara Kualitas Pelayanan denga Kepuasan Nasabah, dinyatakan dalam rumus regresi linier sederhana.

a. Menghitung Konstanta (a) :

b. Menghitung Koefisien Regresi (b)

c. Menghitung Persamaan Regresi

Berdasarkan hasil perhitungan di atas dapat dijelaskan sebagai berikut :

1) Nilai konstanta intersep sebesar 8,96 menunjukkan bahwa tanpa kualitas pelayanan, kepuasan nasabah tetap terbentuk sebesar 8,96.

2) Variabel Kualitas Pelayanan berpengaruh positif terhadap Kepuasan Nasabah dengan nilai koefisien sebesar 0,38. Artinya, jika Kualitas Pelayanan meningkat satu satuan, maka Kepuasan Nasabah akan meningkat sebesar 0,38.

\section{d. Hasil Uji Koefisien Korelasi Product Moment}


Untuk mengetahui kuat lemahnya (derajat hubungan) pengaruh kualitas pelayanan $(\mathrm{X})$ terhadap kepuasan Nasabah $(\mathrm{Y})$ dapat dihitung dengan menggunakan korelasi product moment

Berdasarkan perhitungan, maka diperoleh nilai $r=0,7796$. Nilai $r$ tersebut jika kita hubungkan dengan tabel interpretasi koefisien korelasi artinya ada hubungan atau pengaruh positif yang "Kuat" antara Kualitas Pelayanan (Variabel X) terhadap Kepuasan Nasabah (VariabelY).

\section{e. Hasil Uji Koefisien Determinasi}

Koefisien determinasi digunakan untuk mengetahui besar dan kecilnya pengaruh variabel $\mathrm{X}$ (kualitas Pelayanan) terhadap variabel $\mathrm{Y}$ (Kepuasan Nasabah) dapat ditentukan dengan rumus koefisien determinasi

Data ini mengindikasikan bahwa Kualitas Pelayanan $(X)$ terhadap Kepuasan Nasabah (Y) memberikan kontribusi sebesar 60,78\%, sedangkan sisanya yaitu sebesar $39,22 \%$ keputusan pembelian dipengaruhi oleh faktor lain yang tidak diteliti oleh peneliti.

\section{f. Hasil Uji Hipotesis}

Uji t dilakukan untuk mengetahui besarnya pengaruh masing-masing variabel bebas secara individual terhadap variabel terikat. Pengujian pengaruh antara variabel Kualitas Pelayanan (X) terhadap Kepuasan Nasabah (Y) dapat dilakukan dengan uji statistik t (uji parsial). Sebagai pembanding untuk melihat pengaruh signifikan sebesar $5 \%(0,05)$ dan membandingkan $t$ hitung dengan $t$ tabel dengan kriteria sebagai berikut :

1) Jika $t_{\text {hitung }} \leq t$ tabel berarti Ho diterima dan Ha ditolak.

2) Jika $t$ hitung $\geq t$ tabel berarti Ho ditolak dan Ha diterima.

Adapun ketentuan $\mathrm{t}$ tabel diperoleh dengan cara jumlah responden (85 orang) dikurang jumlah variabel 2 sama dengan 83, dilihat dari distribusi nilai $t$ tabel (terlampir) maka nilai $t_{\text {tabel }}$ adalah sebesar 1,989.

Berdasar data ini didapatkan nilai $t_{\text {hitung }}$ lebih besar dari $t_{\text {tabel }}$ sebesar 11,34 > 1,989. Dari hasil ini maka terjawab Ho ditolak dan Ha diterima, artinya kualitas pelayanan (X) memiliki pengaruh yang signifikan terhadap kepuasan nasabah (Y).

\section{G. Kesimpulan}

Penelitian dilakukan pada responden Bank Mandiri KCM Jakarta Raya Kosambi, untuk mengetahui pengaruh Kualitas Pelayanan terhadap Kepuasan Nasabah. 
Berdasarkan hasil analisis dan pembahasan pada bab sebelumnya, maka dapat diambil kesimpulan sebagai berikut :

1. Kualitas Pelayanan (X) pada Bank Mandiri KCM Jakarta Raya Kosambi Jakarta Barat keseluruhan dalam kategori baik. Hal ini dapat dilihat dari jumlah responden yang mayoritas menjawab setuju sebesar $49,4 \%$ dan menjawab sangat setuju sebesar $21,3 \%$ sehingga total yang menjawab setuju dan sangat setuju adalah sebesar $70,7 \%$. Perhitungan skor yang dilakukan menunjukkan nilai dalam kategori "Baik".

2. Kepuasan Nasabah (Y) pada Bank Mandiri KCM Jakarta Raya Kosambi Jakarta Barat berdasarkan jawaban responden sebanyak 85 orang secara keseluruhan dalam kategori baik. Hal ini terbukti dari jumlah responden yang menjawab setuju sebesar $54 \%$ dan sangat setuju sebesar $24,1 \%$ sehingga total yang menjawab setuju dan sangat setuju adalah sebesar $78,1 \%$. Perhitungan skor yang dilakukan menunjukkan nilai dalam kategori "Baik".

3. Terdapat pengaruh yang positif dan signifikan dari Kualitas Pelayanan terhadap Kepuasan Nasabah pada Bank Mandiri KCM Jakarta Raya Kosambi Jakarta Barat. Hasil uji Regresi Linier Sederhana konstanta 8,96. Menyatakan bahwa tanpa upaya pelayanan yang berkualitas, Kepuasan Nasabah tetap terbentuk 8,96 dan Variabel Kualitas Pelayanan berpengaruh positif terhadap Kepuasan Nasabah dengan nilai koefisien sebesar 0,38 Artinya jika variabel Kualitas Pelayanan meningkat satu satuan, maka Kepuasan Nasabah akan meningkat sebesar 0,38. Koefisien korelasi didapatkan hasil sebesar 0,7796, artinya ada pengaruh positif yang "Kuat" antara Kualitas Pelayanan (Variabel X) terhadap Kepuasan Nasabah (Variabel Y). Nilai koefisien determinasi didapatkan $60,78 \%$ yang mengindikasikan Kualitas Pelayanan (X) terhadap Kepuasan Nasabah (Y) memberikan kontribusi sebesar 60,78\%, sedangkan sisanya 39,22\% dipengaruhi oleh faktor lain. Hasil uji t memberikan hasil nilai $t_{\text {hitung }}$ lebih besar dari $t$ tabel sebesar 11,34 > 1,989. Dari hasil ini maka terjawab Ho ditolak dan Ha diterima, dan hal ini menunjukkan bahwa Kualitas Pelayanan (X) memiliki pengaruh yang positif dan signifikan terhadap Kepuasan Nasabah (Y).

\section{H. Daftar Pustaka}

Agung, Yuliana. 2005. Strategi Pemasaran. Yogyakarta: Andi Offset.

Alma, Buchari. 2007. Manajemen Pemasaran \& Pemasaran Jasa. Bandung: CV. Alfabeta. 
Arikunto, Suharsimi. 2006. Dasar-dasar Evaluasi Pendidikan. Jakarta: Aneka Cipta. Basu Swastha, DH dan Irawan. 2000. Manajemen Pemasaran Modern. Edisi kedua. Yogyakarta: Liberty.

Fandy Tjiptono. 2004. Strategi Pemasaran, Edisi Kedua. Yogyakarta: Andi.

Ghozali, Imam. 2002. Aplikasi Analisis Multivariat dengan Program SPSS. Semarang: Badan Penerbit Universitas Diponegoro.

Ghozali, Imam. 2005. Aplikasi Analisis Multivariat dengan Program SPSS. Semarang: Badan Penerbit Universitas Diponegoro.

Ghozali, Imam. 2009. Aplikasi Analisis Multivariat dengan Program SPSS. Edisi Keempat. Semarang: Badan Penerbit Universitas Diponegoro.

Goetsch dan Davis. 1994. Manajemen Mutu Terpadu. Edisi Kedua. Bogor : Ghalia Indonesia.

Guilford, J.P. 1956. Fundamental Statistics in Psychology and Education. 3rd Ed. New York: McGraw-Hill Book Company.Inc

Hasibuan, Malayu S.P. 2008. Manajemen Sumber Daya Manusia. Jakarta: PT Bumi Aksara.

Hawkins, Dell dan Loney Dalam Buku Fandy Tjiptono. 2004, Strategi Pemasaran, Edisi Kedua. Yogyakarta. Andi

Irawan. 2008. Manajemen Pemasaran Moderen. Yogyakarta : Liberty.

Sugiyono. Metode Penelitian Bisnis. Bandung : CV Alfabeta.

Kasmir. 2004. Bank Dan Lembaga Keuangan Lainnya. Jakarta: PT Raja Grafindo Persada.

Kotler, Philip. 2000. Manajemen Pemasaran. Edisi Milenium, Jakarta: Prahelindo.

Kotler, Philip dan Gary Armstrong. 2001. Prinsip-Prinsip Pemasaran. Jilid 1 Edisi Kedelapan. Jakarta: Erlangga.

Kotler, Phillip dan Gary Armstrong. 2001,Prinsip-Prinsip Pemasaran Jilid 2, Edisi Kedelapan. Jakarta: Erlangga.

Kotler, Phillip dan Gary Amstrong. 2002. Manajemen Pemasaran. Jilid 1. Edisi Milenium. Jakarta: Prahelindo.

Kotler, Philip dan Gary Armstrong, 2003. Dasar-Dasar Pemasaran. Jilid 2. Edisi Kesembilan. Jakarta: PT. Indeks Kelompok Gramedia.

Kotler, Philip and Gary Armstrong. 2005.Manajemen Pemasaran. Jilid 1 Dan 2. Jakarta: PT. Indeks Gramedia.

Kotler, Philip. 2009. Manajemen Pemasaran. Jilid 1 Dan 2, Edisi Kesebelas. Jakarta: PT Indeks Gramedia. 
Kotler, Philip Dan Kevin Lane Keller. 2009. Manajemen Pemasaran Jilid 1 Dan 2. Edisi Ketigabelas. Terjemahan Bob Sabran,MM. Jakarta: Erlangga.

Lovelock, Christopher dan Lauren K. Wright. 1994. Manajemen Pemasaran Jasa, Alih bahasa Agus Widyantoro. Cetakan Kedua. Jakarta: PT. INDEKS.

Lupiyoadi, Rambat. 2009. Manajemen Pemasaran Jasa: Teori dan Praktek. Jakarta: Salemba Empat.

Rangkuti, Freddy. 2002. Riset Pemasaran. Jakarta: PT Gramedia Pustaka.

Riduwan. 2008. Dasar-dasar Statistika. Bandung: Alfabeta.

Saladin. Jaslim. 2003. Intisari Pemasaran Dan Unsur-Unsur Pemasaran. Cetakan Ketiga. Banding: Alfabeta.

Stanton, William J. 2002. Strategi Pemasaran Jilid 1. Cetakan Keenam. Yogyakarta: Andi.

Sugiyono. 2002. Statistika Untuk Penelitian. Cetakan kedelapan. Bandung: CV. Alfabeta.

Sugiyono. 2005. Metode Penenlitian Administrasi. Bandung: CV. Alfabeta.

Sugiyono. 2006. Metode Penelitian Pendekatan Kuantitatif, Kualitatif, dan R\&D. Bandung: CV. Alfabeta.

Sugiyono. 2008. Metode Penelitian Bisnis. Edisi 2. Bandung: CV. Alfabeta.

Sugiyono. 2010. Metode Penelitian Kuantitatif Kualitatif dan $R$ \& $D$. Bandung: CV. Alfabeta.

Sugiyono. 2011. Metode Penelitian Kuantitatif Kualitatif dan $R \& D$. Cetakan keempat Belas. Bandung: CV. Alfabeta.

Sugiyono. 2012. Metode Penelitian Kuantitatif Kualitatif dan $R \& D$. Bandung: CV. Alfabeta.

Sugiyono. 2013. Statistika Untuk Penelitian. Bandung: CV. Alfabeta.

Supranto J. 2006. Pengukuran Tingkat Kepuasan Pelanggan Untuk Menaikan Pangsa Pasar. Jakarta: Bineka Cipta.

Tjiptono, Fandy. 1995. Strategi Pemasaran. Yogyakarta: Andi Offset.

Tjiptono, Fandy. 2000. Manajemen Jasa. Edisi Pertama. Yogyakarta: Andi Offset.

Tjiptono, Fandy. 2004. Manajemen Jasa Edisi Kedua. Yogyakarta: Andi Offset.

Tjiptono, Fandy. 2005. Manajemen Jasa. Malang: Bayumedia Publishing.

Tjiptono, Fandy. 2008. Strategi Pemasaran. Edisi Ketiga. Yogyakarta: Andi Offset.

Terry, George R. 2003. Prinsip-prinsip Manajemen. Jakarta: PT. Bumi Aksara.

Walgito. 2003. Psikologi Umum. Yogyakarta: Andi Offset.

\section{Skripsi/Thesis/Disertasi}


Agustin, Melly, 2011, Pengaruh Kualitas Pelayanan Terhadap Kepuasan Nasabah Pada PT. Bank Mega Tbk, Kantor Cabang Kalimalang. Jakarta: Universitas Gunadarma.

Musliawati, 2015, Pengaruh Kualitas Pelayanan Terhadap Kepuasan Nasabah Pada Bank Mandiri Cabang Cipondoh. Tangsel: Universitas Pamulang.

Sibinus, Theo S.A.S, 2016, Pengaruh Kualitas Pelayanan Frontliner Terhadap Kepuasan Nasabah Bank BRI Kantor Cabang Abdul Muis. Jakarta: UIN Syarif Hidayatullah.

Triyono. 2014.Pengaruh Kualitas Pelayanan Terhadap Kepuasan Pelanggan CV. Ria Busana Margonda Depok. Tangsel: Universitas Pamulang.

Yulianti, Fadma. 2013. Pengaruh Kualitas Pelayanan Terhadap Kepuasan Nasabah Tabungan Pada Panin Bank Tbk, Kcp A. Yani. Banjarmasin: STIE Indonesia.

Jurnal :

Anggabrata, Dewa Wisnu. Pengaruh Kualitas Pelayanan Terhadap Kepuasan Nasabah Pada PT. BPR Balidana Niaga Denpasar. E-Jurnal Manajemen Universitas Udayana. Vol.. 4. No. 5. May 2015. Universitras Udayana Denpasar.

Rosita, Rahmi. Pengaruh Kualitas Pelayanan Terhadap Kepuasan Nasabah Bank Di Bekasi. Jurnal Lentera Bisnis Politeknik LP3I. Vol. 4. No. 2. 2015. Politeknik LP3I Jakarta.

Rahmawati, Yulian Belinda. Pengaruh Kualitas Pelayanan Terhadap Kepuasan Nasabah Di PT. Bank Central Asia (BCA) Tbk Cabang Undaan Surabaya. Jurnal Fakultas Ekonomi. Vol. 6. No. 1 2018. Universitas Negeri Surabaya.

Astuti, Widia. Kontribusi Pelayanan Terhadap Kepuasan Nasabah Bank Muamalat KCP Sampit. Jurnal Studi Ilmu Agama dan Masyarakat. Vol. 14. No. 1. 2018. STKIP Muhammadiyah Sampit.

Sukamma, Lia Effi. Pengaruh Kualitas Pelayanan Terhadap Kepuasan Nasabah PT. pegadaian (Persero) Cabang Madala Medan. Jurnal Administrasi Publik Universitas Medan Area. Vol. 2. No.1. 2014. Universitas Medan Area Medan.

\section{Source :}

http//www.bankmandiri.co.id 